Review

\title{
Circulating MicroRNAs: Molecular Microsensors in Gastrointestinal Cancer
}

\section{Moisés Blanco-Calvo ${ }^{1}$, Lourdes Calvo ${ }^{2}$, Angélica Figueroa ${ }^{1}$, Mar Haz-Conde ${ }^{1}$,} Luis Antón-Aparicio ${ }^{1,2,3}$ and Manuel Valladares-Ayerbes ${ }^{1,2, *}$

1 Biomedical Research Institute of A Coruña, As Xubias 84, E-15006 A Coruña, Spain; E-Mails: Moises.Blanco.Calvo@sergas.es (M.B.-C.);

Angelica.Figueroa.Conde-Valvis@sergas.es (A.F.); Maria.del.Mar.Haz.Conde@sergas.es (M.H.-C.); Luis.M.Anton.Aparicio@sergas.es (L.A.-A.)

2 Clinical Oncology Department, A Coruña University Hospital, As Xubias 84, E-15006 A Coruña, Spain; E-Mail: Lourdes.Calvo.Martinez@sergas.es

3 Medicine Department, A Coruña University, Campus de Oza, E-15006 A Coruña, Spain

* Author to whom correspondence should be addressed;

E-Mail: Manuel.Valladares.Ayerbes@sergas.es; Tel.: +34-981-178-000; Fax: +34-981-178-273.

Received: 12 May 2012; in revised form: 1 June 2012 / Accepted: 25 June 2012 /

Published: 9 July 2012

\begin{abstract}
MicroRNAs (miRNAs) are small molecules of single strand non-coding RNAs, which are able to regulate gene expression. miRNAs have been involved in multiple cellular processes, such as proliferation, apoptosis and differentiation, thus alterations in miRNA expression have been shown to be directly linked with the pathological origin of multiple diseases, including cancer. In this way, during last few years, an increasing number of exciting advances have contributed to the understanding of miRNA roles in cancer. Moreover, researchers have exploited the special characteristics of miRNAs, such as the tissue and disease specificity or miRNA presence in blood, to explore their use as non-invasive tumour markers. In the present review, we summarize the current data on the potential usefulness of circulating miRNAs as diagnostic and prognostic tools in gastrointestinal tumours.
\end{abstract}

Keywords: circulating microRNAs; biomarkers; gastrointestinal cancer; oesophageal cancer; gastric cancer; pancreatic cancer; liver cancer; colorectal cancer 


\section{Introduction}

Cancer is a major worldwide health issue and represents the second leading cause of death after cardiovascular diseases [1]. Among cancers, gastrointestinal (oesophageal, gastric, pancreatic, hepatic and colorectal) cancer is one of most diagnosed and, together with breast and lung tumours, is responsible for most deaths. Moreover, despite the intense efforts and advances in the understanding of the molecular causes of this disease, there is no definitive therapeutic solution. Current treatments have improved the curative expectations and the quality of life of patients; however, the effectiveness of these new tools depends largely on the stage in which tumours can be detected. Therefore, it is clearly needed to investigate potential biomarkers with capacity to detect malignancies at early stages and in a fast, simple, sensitive and specific way. While the detection of current cancer biomarkers is sufficiently fast and simple, unfortunately, their diagnostic and prognostic performance is poor, which hinders their clinical use [2]. Moreover, despite the large number of studies on circulating biomarkers for different tumours, few proposals have been translated into clinical practice.

MicroRNAs (miRNAs), small (18-22 nucleotides) single-stranded RNA molecules with regulatory functions [3], have become the focus of most recent efforts in cancer research. The importance of miRNAs lies in their extensive regulatory capacity, since a single miRNA is able to control the expression of hundred of genes [4,5], contributing to the global coordination of complex cellular processes, such as the proliferative control of stem cells [6]. Given this premise, the alteration in miRNA expression is considered one of the molecular abnormalities behind cancer development. In addition, miRNA expression is tissue specific [7] and therefore, the alteration of specific miRNAs in different tissues can be associated with concrete tumours [8]. In fact, it is possible to classify a tumour sample of unknown nature, even a metastatic one, by the identification of the tissue on which the primary tumour has been generated [9]. These characteristics make of miRNAs, powerful tools for diagnostic and prognostic purposes, as well as attractive therapeutic targets in cancer (for review, see [10]). Moreover, miRNAs are detected in blood at multiple physiological and pathological states, including cancer [11]. Most importantly, miRNAs are protected from degradation by ribonucleases in blood [12], enabling their detection and their use as non-invasive biomarkers. In this review, we summarize the current knowledge about the diagnostic and prognostic applications of circulating miRNAs in gastrointestinal cancer.

\section{Sources of Circulating MiRNAs in Cancer}

The origin and function of circulating nucleic acids in cancer, including miRNAs, is still under discussion (for a review, see [13]). The existence of circulating miRNAs in healthy individuals per se [14] or associated to different physiological events, such as pregnancy [15], underlines that their roles are not restricted to cancer. Therefore, circulating miRNAs in cancer may derive from multiple sources, including not only apoptosis and necrosis of circulating and primary tumour cells, but also the active release carried out by immune cells and other blood cells. Although there are different theories, the precise function of these circulating miRNAs in cancer remains unclear. One possibility is that cancer cells liberate immunosuppressive miRNAs allowing the tumour to evade the immune response. Cancer cells may also release oncogenic miRNAs contributing to their uncontrolled proliferation, the 
malignant transformation of surrounding cells and the recruitment of new blood vessels. Alternatively, immune cells may also produce miRNAs to stimulate the response against cancer cells while tumour surrounding cells may generate tumour-suppressive miRNAs to arrest the extension of malignancy (for review, see [16]).

Stability is another additional and interesting characteristic of circulating miRNAs which makes possible their detection and analysis, and, therefore, opening the door to their use as molecular markers. Moreover, this feature suggests that miRNAs do not circulate free in the bloodstream but are released as part of lipid or protein complexes that prevent the action of blood ribonucleases. The nature of these macromolecular complexes is in close relation to the source of transported miRNAs. Thus, while living cells actively release miRNAs encapsulated in large lipoprotein complexes (exosomes or microvesicles), miRNAs from dead or dying cells can be found in blood associated to Argonaute2 (Ago2) protein (for a review, see [10]). Since it has been hypothesised that most extracellular miRNAs, including plasma miRNAs, are part of Ago2 complexes, and given the increased amount of circulating miRNAs in cancer, it is possible speculate that these circulating miRNAs predominantly derive from apoptotic and necrotic processes occurring in tumour cells. Therefore, circulating miRNAs in cancer are a good reflection of the underlying disease, providing valuable tools to monitor the pathological changes during the clinical course of tumours. Taken together this premise and the miRNA tissue specificity, it can be proposed that circulating miRNAs are not only excellent biomarkers for cancer detection but also for prognostic purposes.

\section{Circulating MiRNAs as Biomarkers in Gastrointestinal Cancer}

In the last few years, studies on miRNAs as tumour markers have emerged as a field of special interest in gastrointestinal cancer according to the huge number of publications. However, while most studies are focused on the analysis of miRNA expression in tissue specimens, only a limited number of them have addressed the usefulness of circulating miRNAs as biomarkers in blood, serum or plasma samples. In this section, we will focus on the most relevant findings about the utility of circulating miRNAs as biomarkers in gastrointestinal cancer, i.e., oesophageal, gastric, pancreatic, hepatic and colorectal cancer.

The first attempt to identify circulating miRNAs as biomarkers in oesophageal cancer (Table 1) was made by Zhang and co-workers in 2010 [17]. In this study, a set of seven miRNAs, including miR-10a, miR-22, miR-100, miR-148b, miR-223, miR-133a and miR-127-3p, was identified and validated as a diagnostic signature after analysing 290 serum samples from squamous cell carcinoma (SCC) patients. These seven miRNAs showed excellent diagnostic capacities in combination or as single markers, showing a great area under the Receiver Operating Characteristic (ROC) curves (AUCs). Although the AUC for the seven-miRNA signature was 0.929 , the maximum value reached was for miR-22 serum determination (0.949) and the minimum value for miR-100 (0.817); both values are above the AUC (0.549) for the carcinoembryonic antigen (CEA), a conventional serum marker. In addition, the cluster analysis revealed the ability of seven-miRNA panel to discriminate between early stage patients and healthy subjects. In 2011, two additional reports focused on the diagnostic and prognostic roles of circulating miRNAs in oesophageal cancer were published simultaneously. The first one was focused on the analysis of miR-31 levels in serum from 201 SCC patients as a diagnostic and prognostic tool [18]. 
While the diagnostic performance of miR-31 was high both in the training $(\mathrm{AUC}=0.902)$ and validation $(\mathrm{AUC}=0.888)$ datasets, the most relevant conclusion was the independent association of high serum levels for miR-31 with poor relapse-free survival (hazard ratio: 3.260; 95\% confidence interval: $1.264-8.421 ; p$-value $=0.015)$. In the second study [19], an assay that combines the determination of miR-375 and miR-21 levels (miR-21/miR-375 ratio) in plasma for SCC diagnostic was developed, reaching an AUC of 0.816 .

Table 1. Circulating miRNAs with diagnostic and prognostic applications in oesophageal cancer.

\begin{tabular}{|c|c|c|c|c|c|c|}
\hline miRNAs & Samples (n) & $\begin{array}{l}\text { TNM }{ }^{1} \text { Stage } \\
\text { (patients) }\end{array}$ & Technique & $\begin{array}{c}\text { Up/ } \\
\text { Down }{ }^{2}\end{array}$ & Association & Ref. $^{3}$ \\
\hline $\begin{array}{l}\text { 7-miRNA panel: } \\
\text { miR-10a, miR-22, } \\
\text { miR-100, miR-133a, } \\
\text { miR-127-3p, } \\
\text { miR-148b, miR-223 }\end{array}$ & $\begin{array}{c}\text { Serum } \\
\text { (290 patients, } \\
140 \text { controls })\end{array}$ & $\begin{array}{l}0 \text { (2), I (18), } \\
\text { II (81), } \\
\text { III (31), } \\
\text { IV (11), } \\
X^{6}(6)\end{array}$ & $\begin{array}{c}\text { Deep-sequencing + } \\
\text { qRT-PCR }^{4}\end{array}$ & $\mathrm{Up}$ & Diagnosis of SCC & [17] \\
\hline miR-31 & $\begin{array}{c}\text { Serum } \\
\text { (201 patients, } \\
202 \text { controls) }\end{array}$ & $\begin{array}{l}\text { I (28), II (31), } \\
\text { III (33), } \\
\text { IV (28) }\end{array}$ & qRT-PCR & $\mathrm{Up}$ & $\begin{array}{c}\text { Poor relapse-free } \\
\text { and tumour-specific } \\
\text { survival/Diagnosis } \\
\text { of SCC }\end{array}$ & [18] \\
\hline $\begin{array}{l}\text { miR-21/ } \\
\text { miR-375 ratio }\end{array}$ & $\begin{array}{c}\text { Plasma } \\
\text { (50 patients, } \\
20 \text { controls })\end{array}$ & $\begin{array}{l}\text { I-II (25), } \\
\text { III-IV (25) }\end{array}$ & qRT-PCR & Up & Diagnosis of SCC ${ }^{5}$ & [19] \\
\hline
\end{tabular}

${ }^{1}$ Tumor, Node, Metastasis staging system; ${ }^{2}$ Up-regulation or Down-regulation regarding control samples;

${ }^{3}$ References; ${ }^{4}$ Quantitative reverse transcription polymerase chain reaction; ${ }^{5}$ Squamous cell carcinoma;

${ }^{6}$ Unknown.

Regarding gastric cancer (Table 2), an incipient study published by Tsujiura and co-workers [20] evaluated by qRT-PCR the usefulness as diagnostic markers of five miRNAs (miR-17-5p, miR-21, miR-106a, miR-106b and let-7a) in plasma from 69 patients and 30 healthy individuals. The analysis of individual ROC curves demonstrated that miR-106b had the best AUC (0.721), while the combined assay for miR-106a/let-7a ratio improved this AUC, reaching 0.879. Therefore, miR-106b expression and miR-106a/let-7a ratio were proposed as the first non-invasive plasma biomarkers for gastric cancer diagnosis. MiR-106a was also detected in blood from gastric cancer patients and it was proposed to be a potential biomarker for detecting circulating tumour cells [21]. On the other hand, miR-17 alone or in combination with miR-106a, showed superior diagnostic properties as show the AUCs obtained from ROC curve analysis ( 0.684 for miR-106a, 0.743 for miR-17, and 0.741 for the combination) [21]. More recent and extensive studies investigated, by genome-wide approaches, circulating miRNAs with potential diagnostic applications in gastric cancer [22-24]. In one of these studies, Solexa sequencing was performed to discover miRNAs differentially expressed in pooled serum samples from 20 metastatic, 20 non-metastatic and 20 healthy donors. From this discovery stage, 22 miRNA candidates were selected and subsequently analysed by qRT-PCR in a training cohort of 22 gastric cancer cases and 22 controls. The five-miRNA signature (miR-1, miR-20a, miR-27a, miR-34 and miR-423-5p) thus identified was further validated by analysing serum from 142 gastric cancer patients and 105 matched controls. Both in training and validation datasets, the five-miRNA panel reached excellent diagnostic 
properties with respective AUCs of 0.879 and 0.831, clearly superior to AUCs obtained for the CA19-9 carbohydrate antigen and CEA (0.600 and 0.503, respectively) [22]. Other studies were performed using microarrays instead deep sequencing in the phase of biomarker discovery. Liu and co-workers [23] obtained seven miRNA candidates that were subsequently analysed by qRT-PCR in a training cohort of 30 gastric cancer patients and 30 healthy controls. Only three of them (miR-187*, miR-371-5p and miR-378) were selected for further validation in a cohort consisting of serum from 40 gastric cancer patients and 41 controls. The best AUC was obtained for miR-378 (0.861); in addition, a multivariate analysis, including the three candidate miRNAs, demonstrated that only miR-378 had diagnostic independence (odds ratio: 16.917; 95\% confidence interval: 5.337-53.616; $p$-value < 0.0001) [23]. Microarrays were also used by Konishi and colleagues to identify miR-451 and miR-486 as plasma biomarkers for gastric cancer detection (respective AUCs: 0.96 and 0.92) [24]. However, Song and colleagues used qRT-PCR low-density arrays to identify miRNA biomarkers in serum of gastric cancer patients [25]. The panel of miRNAs obtained (miR-221, miR-376c, and miR-744) showed the best sensitivity (0.824) and specificity (0.588), using the cut-off values obtained from the analyses of ROC curves for each miRNA (AUCs: 0.70 for miR-221; 0.71 for miR-376c; and 0.74 for miR-744).

Table 2. Circulating miRNAs with diagnostic and prognostic applications in gastric cancer.

\begin{tabular}{|c|c|c|c|c|c|c|}
\hline miRNAs & Samples (n) & $\begin{array}{c}\text { TNM }{ }^{1} \text { Stage } \\
\text { (patients) }\end{array}$ & Technique & $\begin{array}{c}\text { Up/ } \\
\text { Down }^{2}\end{array}$ & Association & Ref. $^{3}$ \\
\hline $\operatorname{miR}-106 b$ & $\begin{array}{c}\text { Plasma } \\
\text { (69 patients, } \\
30 \text { controls) }\end{array}$ & $\begin{array}{l}\text { I (38), II (13), } \\
\text { III (14), IV (4) }\end{array}$ & $\mathrm{qRT} \mathrm{PCR}{ }^{4}$ & $\mathrm{Up}$ & $\begin{array}{l}\text { Gastric cancer } \\
\text { diagnosis }\end{array}$ & {$[20]$} \\
\hline $\begin{array}{l}\text { miR-106a/ } \\
\text { let-7a ratio }\end{array}$ & $\begin{array}{c}\text { Plasma } \\
\text { (69 patients, } \\
30 \text { controls) }\end{array}$ & $\begin{array}{l}\text { I (38), II (13), } \\
\text { III (14), IV (4) }\end{array}$ & qRT-PCR & Up & $\begin{array}{l}\text { Gastric cancer } \\
\text { diagnosis }\end{array}$ & {$[20]$} \\
\hline miR-17, miR-106a & $\begin{array}{c}\text { Blood } \\
\text { (90 patients, } \\
27 \text { healthy } \\
\text { controls) }\end{array}$ & Not provided & qRT-PCR & Up & $\begin{array}{l}\text { Circulating } \\
\text { tumour cell } \\
\text { detection; } \\
\text { gastric cancer } \\
\text { diagnosis }\end{array}$ & {$[21]$} \\
\hline $\begin{array}{l}\text { 5-miRNA signature: } \\
\text { miR-1, miR-20a, } \\
\text { miR-27a, miR-34, } \\
\text { miR-423-5p }\end{array}$ & $\begin{array}{c}\text { Serum } \\
\text { (164 patients, } \\
127 \text { controls })\end{array}$ & $\begin{array}{c}\text { I (29), II (56), } \\
\text { III (48), IV (23), } \\
X^{5}(8)\end{array}$ & $\begin{array}{c}\text { Deep } \\
\text { sequencing + } \\
\text { qRT-PCR }\end{array}$ & Up & $\begin{array}{l}\text { Gastric cancer } \\
\text { diagnosis }\end{array}$ & {$[22]$} \\
\hline $\operatorname{miR}-378$ & $\begin{array}{c}\text { Serum } \\
\text { (57 patients, } \\
61 \text { controls })\end{array}$ & $\begin{array}{c}\text { I (6), II (14), } \\
\text { III (18), IV (19) }\end{array}$ & $\begin{array}{c}\text { Microarray + } \\
\text { qRT-PCR }\end{array}$ & Up & $\begin{array}{l}\text { Gastric cancer } \\
\text { diagnosis }\end{array}$ & {$[23]$} \\
\hline miR-451, miR-486 & $\begin{array}{c}\text { Plasma } \\
\text { (56 patients, } \\
30 \text { controls })\end{array}$ & $\begin{array}{l}\text { I+II (33), } \\
\text { III-IV (23) }\end{array}$ & $\begin{array}{c}\text { Microarray + } \\
\text { qRT-PCR }\end{array}$ & Up & $\begin{array}{l}\text { Gastric cancer } \\
\text { diagnosis }\end{array}$ & {$[24]$} \\
\hline $\begin{array}{c}\mathrm{miR}-221, \mathrm{miR}-376 \mathrm{c} \\
\mathrm{miR}-744\end{array}$ & $\begin{array}{c}\text { Serum } \\
\text { (82 patients, } \\
82 \text { controls })\end{array}$ & Not provided & $\begin{array}{l}\text { qRT-PCR } \\
\text { array }\end{array}$ & Up & $\begin{array}{l}\text { Gastric cancer } \\
\text { diagnosis }\end{array}$ & {$[25]$} \\
\hline miR-17-5p, miR-20a & $\begin{array}{c}\text { Plasma } \\
\text { (87 patients) }\end{array}$ & $\begin{array}{c}\mathrm{I}+\mathrm{II}(40), \text { III (37), } \\
\text { IV (10) }\end{array}$ & qRT-PCR & Up & $\begin{array}{l}\text { Poorer overall } \\
\text { survival }\end{array}$ & {$[26]$} \\
\hline
\end{tabular}

\footnotetext{
${ }^{1}$ Tumor, Node, Metastasis staging system; ${ }^{2}$ Regarding control samples; ${ }^{3}$ References; ${ }^{4}$ Quantitative reverse
} transcription polymerase chain reaction; ${ }^{5}$ Unknown. 
Finally, a recent study analysed the correlation between plasma miRNA levels and prognostic variables in gastric cancer [26]. They demonstrated that patients with elevated levels of miR-17-5p and miR-20a in plasma showed lower overall survival ( $p$-value $=0.003$ for both miRNAs). Moreover, as indicated by multivariate analysis, increased plasma levels of miR-20a was an independent risk factor for shorter overall survival in these patients (hazard ratio: 1.576; 95\% confidence interval: 1.102-2.253; $p$-value $=0.013$ ).

The first study on circulating miRNAs as biomarkers in pancreatic cancer patients was performed in 2009 by Wang and co-workers (Table 3) [27]. The authors analysed by qRT-PCR the expression of four miRNAs (miR-21, miR-210, miR-155 and miR-196a) in plasma from 49 pancreatic ductal adenocarcinoma (PDAC) patients and 36 healthy controls, achieving a good diagnostic performance for this miRNA panel. While the independent analysis of ROC curves for each miRNA gave rise to AUCs ranging from 0.62 (miR-21) to 0.69 (miR-196a), the combination of the entire panel improved the AUC (0.82) as well as the sensitivity (0.64) and specificity (0.89) at the optimal cut-point. In another posterior study, high levels of miR-196a in serum were associated with unresectable PDACs $(A U C=0.864)$ and shorter survival [28]. The same group analysed the expression of seven miRNAs (miR-16, miR-21, miR-155, miR-181a, miR-181b, miR-196a and miR-210) in plasma from pancreatic cancer patients, chronic pancreatitis patients and healthy individuals [29]. While the individual miRNAs reached good diagnostic properties, the combination of miR-16 and miR-196a provided the best results. The diagnostic capacity of this miRNA panel was further improved when it was combined with CA19-9 levels, increasing the AUC, specificity and sensitivity. Most importantly, the combinatory marker (miR-16 + miR-196a + CA19-9) showed an enhanced capacity for the detection of stage I pancreatic cancer compared to CA19-9 (respective detection rates: 85.2\% and 55.6\%). Two groups further explored the role of circulating miRNAs as diagnostic tools in pancreatic cancer. First, miR-18a was established as a powerful biomarker (AUC $=0.9369$ ) for pancreatic cancer diagnostic in plasma [30]. Second, an extensive genome-wide analysis was performed by deep-sequencing in order to discover miRNAs with altered expression in serum from pancreatic cancer patients, followed by testing and validation of their potential diagnostic usefulness [31]. The analysis demonstrated the ability of a seven-miRNA signature (miR-20a, miR-21, miR-24, miR-25, miR-99a, miR-185, and miR-191) to discriminate pancreatic cancer from healthy controls $(\mathrm{AUC}=0.992, p$-value $=0.027$ in training cohort; $\mathrm{AUC}=0.985, p$-value $=0.027$ in validation cohort $)$ and from chronic pancreatitis $(\mathrm{AUC}=0.993 ; p$-value $=0.008)$. More importantly, this seven-miRNA panel can be also used to detect pancreatic cancer cases at early stages (detection rates: $96.2 \%$ and $91.7 \%$ of cases at stages I and II), clearly improving the detection rates of conventional serum markers CA19-9 (detection rates: $46.2 \%$ and $62.5 \%$ of cases at stages I and II) and CEA (detection rates: $30.8 \%$ and $31.3 \%$ of cases at stages I and II). In addition, elevated levels of miR-21 in serum were identified as an independent predictor of poor survival in pancreatic cancer patients (Hazard ratio: 8.77 ; 95\% confidence interval: $2.00-38.39$; $p$-value $<0.01$ ). 
Table 3. Circulating miRNAs with diagnostic and prognostic applications in pancreatic cancer.

\begin{tabular}{|c|c|c|c|c|c|c|}
\hline miRNAs & Samples (n) & $\begin{array}{c}\text { Stage } \\
\text { (patients) }\end{array}$ & Technique & $\begin{array}{c}\text { Up/ } \\
\text { Down }^{1}\end{array}$ & Association & Ref. $^{2}$ \\
\hline $\begin{array}{l}\text { 4-miRNA } \\
\text { signature: miR-21, } \\
\text { miR-210, miR-155, } \\
\text { miR-196a }\end{array}$ & $\begin{array}{c}\text { Plasma } \\
\text { (49 patients, } \\
36 \text { controls) }\end{array}$ & $\begin{array}{l}\text { Localized (15), } \\
\text { locally } \\
\text { advanced (13), } \\
\text { metastatic (21) }\end{array}$ & qRT-PCR ${ }^{3}$ & $\mathrm{Up}$ & $\begin{array}{c}\text { Diagnosis of } \\
\text { pancreatic } \\
\text { adenocarcinoma }\end{array}$ & [27] \\
\hline miR-196a & $\begin{array}{c}\text { Serum } \\
(35 \text { patients, } \\
15 \text { pancreatitis, } \\
15 \text { controls })\end{array}$ & $\begin{array}{l}\text { TNM }^{4}: \text { IB (9), } \\
\text { IIA (6), IIB (9), } \\
\text { III (5), IV (6) }\end{array}$ & qRT-PCR & Up & $\begin{array}{l}\text { Un-resectability } \\
\text { and short survival }\end{array}$ & [28] \\
\hline $\begin{array}{c}\text { 2-miRNA } \\
\text { signature: miR-16, } \\
\text { miR-196a } \\
\left( \pm \mathrm{CA}^{5} 19-9\right)\end{array}$ & $\begin{array}{c}\text { Plasma } \\
\text { (138 tumours, } \\
107 \text { pancreatitis, } \\
68 \text { controls })\end{array}$ & $\begin{array}{l}\text { TNM: I (27), } \\
\text { II (39), III (17), } \\
\text { IV (55) }\end{array}$ & qRT-PCR & Up & $\begin{array}{l}\text { Early diagnosis of } \\
\text { pancreatic cancer; } \\
\text { chronic pancreatitis } \\
\text { diagnosis }\end{array}$ & [29] \\
\hline miR-18a & $\begin{array}{c}\text { Plasma } \\
\text { (36 patients, } \\
30 \text { controls) }\end{array}$ & $\begin{array}{l}\text { TNM: Ib (1), } \\
\text { IIa (7), IIb (13), } \\
\text { IV (8) }\end{array}$ & qRT-PCR & $\mathrm{Up}$ & $\begin{array}{c}\text { Diagnosis of } \\
\text { pancreatic cancer }\end{array}$ & {$[30]$} \\
\hline $\begin{array}{l}\text { 7-miRNA panel: } \\
\text { miR-20a, miR-21, } \\
\text { miR-24, miR-25, } \\
\text { miR-99a, miR-185, } \\
\text { miR-191 }\end{array}$ & $\begin{array}{c}\text { Serum } \\
\text { (197 tumours, } \\
82 \text { pancreatitis, } \\
158 \text { healthy } \\
\text { donors) }\end{array}$ & $\begin{array}{l}\text { TNM: I (26), } \\
\text { II (48), III (45), } \\
\text { IV (66), } \\
\text { X }^{6}(12)\end{array}$ & $\begin{array}{c}\text { Deep } \\
\text { sequencing }+ \\
\text { qRT-PCR }\end{array}$ & $\mathrm{Up}$ & $\begin{array}{l}\text { Early diagnosis of } \\
\text { pancreatic cancer }\end{array}$ & {$[31]$} \\
\hline $\operatorname{miR}-21$ & $\begin{array}{c}\text { Serum } \\
\text { (38 tumours) }\end{array}$ & Not provided & qRT-PCR & $\mathrm{Up}$ & Poor survival & {$[31]$} \\
\hline
\end{tabular}

Up to date, most studies on liver cancer have focused on the most prevalent subtype, the hepatocellular carcinoma (HCC), and its close relationship with hepatitis B virus (HBV) infection and cirrhosis. This is also extensible to studies on circulating miRNAs and biomarker discovery (Table 4). In 2009, Yamamoto and co-workers reported the first work where significantly higher levels of miR-500 in serum of HCC patients were found, although diagnostic performance data were not provided [32]. Later on, for the first time, Gui and co-workers provided data on the diagnostic capacity of a circulating miRNA, miR-885-5p, in HCC. They obtained miR-885-5p from a global serum miRNA profiling using qRT-PCR low-density arrays. The AUC for the determination of miR-885-5p levels in serum was 0.904 , which allowed to discriminate patients with different liver pathologies (HCC, chirrosis, and chronic hepatitis B) from healthy controls with a sensitivity of $90.53 \%$ and a specificity of $79.17 \%$ [33]. A more comprehensive study was conducted by using deep-sequencing technology, achieving the identification of two miRNA signatures in serum that allow the diagnosis of hepatitis $\mathrm{B} / \mathrm{C}$ infection and hepatitis B virus (HBV)-associated HCC [34]. The miRNA signature for HBV-associated HCC diagnosis was composed of miR-25, miR-375, and let-7f. These miRNAs were able to discriminate cases from healthy controls with excellent specificity and sensitivity (99.1\% and 97.9\%, respectively; AUC: 0.9967). Interestingly, a single component of the previous signature, miR-375, maintains exceptional diagnostic 
parameters with a specificity of $96 \%$ and a sensitivity of $100 \%$. In a similar way, two miRNAs, miR-10a and miR-125b, were capable to distinguish HBV-infected patients from HBV-associated HCC cases with a specificity and sensitivity of $98.5 \%$, and an AUC of 0.992 [34]. A later work performed also on serum samples allowed the discovery of miR-21, miR-122 and miR-223 as excellent biomarkers for HCC (respective AUCs = 0.87, 0.79 and 0.86) and chronic hepatitis (respective AUCs =0.91, 0.93 and 0.88) [35]. Moreover [36], on the basis of previous works, seven miRNAs (miR-1, miR-16, miR-122a, miR-139, miR-195, miR-199a, and miR-224) were evaluated in serum with the purpose to discriminate HCC from chronic liver diseases. Since miR-1, miR-122a, miR-139, and miR-224 were undetectable in serum, the diagnostic reliability for HCC detection was determined for the remaining miRNAs (miR-16, miR-199a, and miR-195). From these three miRNAs, only miR-16 and miR-199a showed capacity to separate patients with HCC from those with chronic liver disease. By using the cut-off values provided by the distribution curves of each miRNA, both miRNAs showed superior sensitivity than conventional serum markers (AFP: $\alpha$-fetoprotein; AFP-L3: Lens culinaris agglutinin-reactive $\alpha$-fetoprotein; DCP: des- $\gamma$-carboxyprothrombin) to separate HCC and chronic liver diseases. The best sensitivity (92.4\%) and specificity (78.5\%) was achieved by the combination of miR-16 with conventional serum markers. MiR-16 used in second-line testing, after conventional serum markers, was also able to detect HCC in $69.2 \%$ of initially negative cases. By a genome-wide exploratory approach, similar to the procedure used by Lee and co-workers in a previous work [34] but based on microarray analysis instead of deep sequencing, plasma miRNAs were recently identified as biomarkers for HBV-related HCC diagnosis [37]. Seven plasma miRNAs (miR-122, miR-192, miR-21, miR-223, miR-26a, miR-27a, and miR-801) were proposed as diagnostic signature with capacity to discriminate HBV-related HCC from healthy controls (specificity: 93.9\%; sensitivity: 83.2\%; AUC: 0.941) and hepatitis B (specificity: 79.1\%; sensitivity: 76.4\%; AUC: 0.842). Although he components of this miRNA panel do not match to any of the previously employed by $\mathrm{Li}$ and co-workers [34], in other studies [35], however, they have used several of these miRNAs. This is the case of miR-122, which was again identified as serum biomarker to distinguish HBV-related HCC patients from healthy controls $(\mathrm{AUC}=0.869$ ) in the Chinese population [38]. Finally, only one study assessed the usefulness of circulating miRNAs as prognostic tools in HCC [39]. In this study, elevated serum levels of miR-221 were associated to shorter overall survival ( $p$-value $<0.05$ ) and identified as an independent risk factor for poor prognosis in HCC patients (Hazard ratio $=1.903 ; 95 \%$ confidence interval $=1.235-2.981 ; p$-value $=0.018)[39]$.

Table 4. Circulating miRNAs with diagnostic and prognostic applications in HCC ${ }^{1}$.

\begin{tabular}{|c|c|c|c|c|c|c|}
\hline miRNAs & Samples (n) & $\begin{array}{c}\text { Stage } \\
\text { (patients) }\end{array}$ & Technique & $\begin{array}{c}\text { Up/ } \\
\text { Down }^{2}\end{array}$ & Association & Ref. $^{3}$ \\
\hline miR-885-5p & $\begin{array}{c}\text { Serum } \\
\text { (46 tumours, } \\
15 \text { liver diseases, } \\
26 \text { cirrhosis, } \\
23 \mathrm{HBV}, \\
24 \text { controls) }\end{array}$ & $\begin{array}{c}\text { Not } \\
\text { provided }\end{array}$ & $\begin{array}{c}\text { qRT-PCR }{ }^{4} \\
\text { array }\end{array}$ & $\mathrm{Up}$ & $\begin{array}{c}\text { Diagnosis of } \\
\text { liver pathologies }\end{array}$ & {$[33]$} \\
\hline $\begin{array}{l}\text { 3-miRNA } \\
\text { signature: miR-25, } \\
\text { miR-375, let-7f }\end{array}$ & $\begin{array}{l}\text { Serum (55 patients, } \\
50 \text { controls })\end{array}$ & $\begin{array}{c}\text { Not } \\
\text { provided }\end{array}$ & $\begin{array}{c}\text { Deep } \\
\text { sequencing + } \\
\text { qRT-PCR }\end{array}$ & Up & $\begin{array}{c}\text { Diagnosis of } \\
\mathrm{HBV}^{5} \text {-related } \\
\mathrm{HCC}\end{array}$ & [34] \\
\hline
\end{tabular}


Table 4. Cont.

\begin{tabular}{|c|c|c|c|c|c|c|}
\hline miRNAs & Samples (n) & $\begin{array}{c}\text { Stage } \\
\text { (patients) }\end{array}$ & Technique & $\begin{array}{c}\text { Up/ } \\
\text { Down }\end{array}$ & Association & Ref. $^{3}$ \\
\hline $\begin{array}{l}\text { miR-21, miR-122, } \\
\text { miR-223 }\end{array}$ & $\begin{array}{c}\text { Serum } \\
\text { (101 tumours, } \\
48 \mathrm{HBV}, \\
89 \text { healthy controls) }\end{array}$ & Not provided & qRT-PCR & Up & $\begin{array}{l}\text { Detection of } \\
\text { HCC and/or } \\
\text { HBV (liver } \\
\text { injury) }\end{array}$ & {$[35]$} \\
\hline $\begin{array}{c}\text { miR-16 } \\
(+/- \text { conventional } \\
\text { serum markers: } \\
\text { AFP }^{6}, \text { AFP-L3 }^{7}, \\
\left.\text { DCP }^{8}\right)\end{array}$ & $\begin{array}{c}\text { Serum } \\
\text { (105 tumours, } \\
107 \text { chronic liver } \\
\text { diseases, } \\
71 \text { controls })\end{array}$ & $\begin{array}{l}\text { CLIP }^{9}: \\
0-2(48), \\
3-6(15)\end{array}$ & qRT-PCR & Down & $\begin{array}{l}\text { HCC detection } \\
\text { in combination } \\
\text { or in second- } \\
\text { line after testing } \\
\text { conventional } \\
\text { serum makers }\end{array}$ & [36] \\
\hline $\begin{array}{c}\text { 7-miRNA } \\
\text { combination: } \\
\text { miR-21, miR-26a, } \\
\text { miR-27a, miR-122, } \\
\text { miR-192, miR-223, } \\
\text { miR-801 }\end{array}$ & $\begin{array}{c}\text { Plasma } \\
\text { (400 tumours, } \\
116 \text { cirrhosis, } \\
147 \text { HBV, } \\
134 \text { healthy donors) }\end{array}$ & $\begin{array}{c}\text { BCLC }^{10}: \\
0(62), \\
\text { A (243), } \\
\text { B (69), } \\
\text { C (25), } \\
\text { D (1) }\end{array}$ & $\begin{array}{c}\text { Microarray + } \\
\text { qRT-PCR }\end{array}$ & $\begin{array}{c}\mathrm{Up} / \\
\text { Down }\end{array}$ & $\begin{array}{c}\text { Diagnosis of } \\
\text { HBV-related } \\
\text { HCC }\end{array}$ & {$[37]$} \\
\hline miR-122 & $\begin{array}{c}\text { Serum (72 tumours, } \\
48 \mathrm{HBV}, 34 \text { healthy } \\
\text { donors) }\end{array}$ & $\begin{array}{l}\mathrm{TNM}^{11}: \text { I }(8), \\
\quad \text { II (36), } \\
\text { III (20), IV (6) }\end{array}$ & qRT-PCR & Up & $\begin{array}{c}\text { Detection of } \\
\text { HBV-related } \\
\text { HCC }\end{array}$ & [38] \\
\hline $\operatorname{miR}-221$ & $\begin{array}{l}\text { Serum (46 tumours, } \\
20 \text { controls) }\end{array}$ & $\begin{array}{l}\text { TNM: I (16), } \\
\text { II (19), } \\
\text { III-IV (11) }\end{array}$ & qRT-PCR & Up & $\begin{array}{l}\text { Shorter overall } \\
\text { survival }\end{array}$ & [39] \\
\hline
\end{tabular}

${ }^{1}$ Hepatocellular carcinoma; ${ }^{2}$ Regarding control samples; ${ }^{3}$ References; ${ }^{4}$ Quantitative reverse transcription polymerase chain reaction; ${ }^{5}$ Hepatitis B virus; ${ }^{6} \alpha$-fetoprotein; ${ }^{7}$ Lens culinaris agglutinin-reactive $\alpha$-fetoprotein; ${ }^{8}$ des- $\gamma$-carboxyprothrombin; ${ }^{9}$ CLIP (Cancer of the Liver Italian Program) staging system; ${ }^{10}$ Barcelona Clinic Liver Cancer staging system; ${ }^{11}$ Tumor, Node, Metastasis staging system.

Attending to circulating miRNAs in colorectal cancer (Table 5), Chen and colleagues [14] conducted for the first time a comprehensive analysis of expression profile of miRNAs in serum by deep sequencing. They detected several miRNAs differentially expressed in colorectal cancer compared to those found in healthy subjects and lung cancer patients. However, $\mathrm{Ng}$ and co-workers provided data about the diagnostic performance of miRNAs in plasma of colorectal cancer patients [40]. In this study, by analysing 95 miRNAs in plasma form 130 patients and 50 healthy controls, miR-17-3p and miR-92 were demonstrated to be the best tools to detect colorectal cancer with respective AUCs of 0.717 and 0.885. Later on, miR-92 (now renamed as miR-92a) and miR-29a, also demonstrated their capacity, independently or in combination, to successfully discriminate plasma samples from colorectal cancer patients, patients with advanced adenomas and healthy controls [41]. When they were used in combination, miR-92a and miR-29a plasma levels showed AUCs of 0.883 and 0.773 to detect respectively colorectal cancer and adenomas from healthy subjects. MiR-29a levels in serum were also used to detect liver metastasis in colorectal cancer patients with an AUC of 0.803 , reaching a sensitivity and specificity of 0.75 [42]. In relation to prognosis, the abundance of miR-141 in plasma was associated with stage IV colon cancer and it displayed an elevated ability to diagnose this subset 
of patients. This ability is complemented and enhanced when the miR-141 assay is combined with CEA determination. Moreover, high levels of miR-141 in plasma were related to poorer survival in colon cancer patients, independently of tumour stage, gender, and age [44]. Likewise, elevated levels of miR-221 in plasma were also proposed as an independent prognostic factor for overall survival in colorectal cancer patients (hazard ratio: 3.478; 95\% confidence interval: $1.038-11.654 ; p$-value $=0.043$ ) [43]. However, the AUC (0.606) obtained for miR-221 when was used to detect colorectal cancer from healthy controls, was modest in comparison to other circulating miRNA investigated [44].

Table 5. Circulating miRNAs with diagnostic and prognostic applications in colorectal cancer.

\begin{tabular}{|c|c|c|c|c|c|c|}
\hline miRNAs & Samples (n) & $\begin{array}{c}\text { TNM }{ }^{1} \text { Stage } \\
\text { (patients) }\end{array}$ & Technique & $\begin{array}{c}\text { Up/ } \\
\text { Down }{ }^{2}\end{array}$ & Association & Ref. $^{3}$ \\
\hline $\begin{array}{l}\text { miR-17-3p } \\
\text { miR-92 }\end{array}$ & $\begin{array}{l}\text { Plasma ( } 130 \text { CRC } \\
\text { patients, } 50 \text { healthy } \\
\text { controls) }\end{array}$ & $\begin{array}{c}\text { I (6), II (35), } \\
\text { III (39), IV (50) }\end{array}$ & $\mathrm{qRT}^{\mathrm{PRCR}}{ }^{4}$ & Up & $\begin{array}{c}\text { Colorectal cancer } \\
\text { diagnosis }\end{array}$ & [40] \\
\hline $\begin{array}{l}\operatorname{miR}-29 a \\
\text { miR-92a }\end{array}$ & $\begin{array}{c}\text { Plasma ( } 100 \text { CRC } \\
\text { patients, } \\
37 \text { adenomas, } \\
59 \text { healthy controls) }\end{array}$ & $\begin{array}{l}\text { I (27), II (25), } \\
\text { III (38), IV(10) }\end{array}$ & qRT-PCR & Up & $\begin{array}{c}\text { Colorectal cancer } \\
\text { and adenoma } \\
\text { diagnosis }\end{array}$ & [41] \\
\hline $\operatorname{miR}-29 a$ & $\begin{array}{c}\text { Serum } \\
\text { (114 patients) }\end{array}$ & Not provided & qRT-PCR & Up & $\begin{array}{c}\text { Liver metastasis } \\
\text { detection }\end{array}$ & [42] \\
\hline $\begin{array}{l}\operatorname{miR}-141 \\
\left(+\mathrm{CEA}^{5}\right)\end{array}$ & $\begin{array}{c}\text { Plasma (185 CRC } \\
\text { patients, } 76 \text { healthy } \\
\text { controls) }\end{array}$ & $\begin{array}{l}\text { I (11), II (63), } \\
\text { III (49), IV (62) }\end{array}$ & qRT-PCR & Up & Poor survival & [43] \\
\hline $\operatorname{miR}-221$ & $\begin{array}{c}\text { Plasma } \\
\text { (103 patients, } \\
37 \text { healthy controls) }\end{array}$ & I-II (36), III-IV (44) & qRT-PCR & Up & $\begin{array}{l}\text { Colorectal cancer } \\
\text { diagnosis; poor } \\
\text { overall survival }\end{array}$ & [44] \\
\hline
\end{tabular}

${ }^{1}$ Tumor, Node, Metastasis staging system; ${ }^{2}$ Regarding control samples; ${ }^{3}$ References; ${ }^{4}$ Quantitative reverse transcription polymerase chain reaction; ${ }^{5}$ Carcinoembryonic antigen.

\section{Conclusions}

To date, since the discovery of miRNAs as regulatory molecules, a large number of reports have elucidated their function, the mechanisms of action, and their expression profile in a wide spectrum of organisms, samples and conditions. This huge amount of information has led researchers to understand the importance of miRNAs as central players during both the initiation and clinical development of many diseases, including cancer. Beyond the possible therapeutic use, these findings have impelled the research on miRNAs as clinical biomarkers. In fact, the singular characteristics of miRNAs, such as tissue- and disease-specificity, make their use an excellent option to detect physiological and pathological alterations. Thus, miRNAs are able to identify, not only the presence or absence of tumours, but also can determine the primary organ or tissue affected and the clinical and pathological stage. Furthermore, miRNAs can predict risk of progression, relapse, and metastasis, and help to evaluate possible clinical scenarios in relation to the therapy response.

Moreover, because of their presence and stability in different body fluids [45], the primary future application of miRNAs is their utilization as non-invasive markers. However, the promising findings 
performed to date are hampered by the variability in sample sources. In addition to the determination of miRNAs in blood, they have been also successfully isolated from clinically relevant samples, such as stool [46] and urine [47], and from forensic samples, such as saliva and semen [48]. However, the favourite sample type is blood derivative due to the reliable determination of the disease status in these samples and the presence of higher amounts of miRNAs. Among blood derivatives, serum is most frequently used in biomarker studies, probably to avoid the technical issues related to the presence of anticoagulants in plasma. Up to now, no relevant studies have been performed on whole blood, due to the possible interference of miRNAs from blood cells. However, the use of whole blood to search for miRNA biomarkers could be interesting as, conversely to plasma and serum, handling is not necessary prior obtaining the sample. Consequently, this sample type provides a scalable solution for future technological implementations for fast and in situ determinations.

Therefore, due to the obstacles related to heterogeneity of available detection techniques and sample sources, there are few clinical trials conducted to evaluate the potential clinical application of miRNA biomarkers. However, the mentioned impediments will be undoubtedly overcome and the clinical implementation of circulating miRNAs as genuine "microsensors" in cancer will become a reality in the near future.

\section{Acknowledgments}

This work was supported by grants FIS06/1541 (Fondo de Investigación Sanitaria, Instituto de Salud Carlos III, Spain) and PS08/77 (Servicio Galego de Saúde, Spain). M.H.C is supported in part by a grant (CA09/00116) from "Instituto de Salud Carlos III" (Spain). A.F. is supported by a research contract (IPP.08-07) from the "Isidro Parga Pondal” program (Xunta de Galicia, Spain).

\section{References}

1. Jemal, A.; Bray, F.; Center, M.M.; Ferlay, J.; Ward, E.; Forman, D. Global cancer statistics. CA-A Cancer. J. Clin. 2011, 61, 69-90.

2. Hundt, S.; Haug, U.; Brenner, H. Blood markers for early detection of colorectal cancer: A systematic review. Cancer Epidem. Biomarker Prev. 2007, 16, 1935-1953.

3. Bartel, D.P. MicroRNAs: Target recognition and regulatory functions. Cell 2009, 136, 215-233.

4. Brennecke, J.; Stark, A.; Russell, R.B.; Cohen, S.M. Principles of microRNA-Target recognition. PLoS Biol. 2005, 3, e85.

5. Lewis, B.P.; Burge, C.B.; Bartel, D.P. Conserved seed pairing, often flanked by adenosines, indicates that thousands of human genes are microRNA targets. Cell 2005, 120, 15-20.

6. Marson, A.; Levine, S.S.; Cole, M.F.; Frampton, G.M.; Brambrink, T.; Johnstone, S.; Guenther, M.G.; Johnston, W.K.; Wernig, M.; Newman, J.; et al. Connecting microRNA genes to the core transcriptional regulatory circuitry of embryonic stem cells. Cell 2008, 134, 521-533.

7. Liang, Y.; Ridzon, D.; Wong, L.; Chen, C. Characterization of microRNA expression profiles in normal human tissues. BMC Genomics 2007, 8, 166.

8. Lu, J.; Getz, G.; Miska, E.A.; Alvarez-Saavedra, E.; Lamb, J.; Peck, D.; Sweet-Cordero, A.; Ebert, B.L.; Mak, R.H.; Ferrando, A.A.; et al. MicroRNA expression profiles classify human cancers. Nature 2005, 435, 834-838. 
9. Rosenfeld, N.; Aharonov, R.; Meiri, E.; Rosenwald, S.; Spector, Y.; Zepeniuk, M.; Benjamin, H.; Shabes, N.; Tabak, S.; Levy, A.; et al. MicroRNAs accurately identify cancer tissue origin. Nat. Biotechnol. 2008, 26, 462-469.

10. Ajit, S.K. Circulating microRNAs as biomarkers, therapeutic targets, and signaling molecules. Sensors 2012, 12, 3359-3369.

11. Lawrie, C.H.; Gal, S.; Dunlop, H.M.; Pushkaran, B.; Liggins, A.P.; Pulford, K.; Banham, A.H.; Pezzella, F.; Boultwood, J.; Wainscoat, J.S.; et al. Detection of elevated levels of tumour-associated microRNAs in serum of patients with diffuse large B-cell lymphoma. Brit. J. Haematol. 2008, $141,672-675$.

12. Mitchell, P.S.; Parkin, R.K.; Kroh, E.M.; Fritz, B.R.; Wyman, S.K.; Pogosova-Agadjanyan, E.L.; Peterson, A.; Noteboom, J.; O’Briant, K.C.; Allen, A.; et al. Circulating microRNAs as stable blood-based markers for cancer detection. Proc. Natl. Acad. Sci. USA 2008, 105, 10513-10518.

13. Mittra, I.; Nair, N.K.; Mishra, P.K. Nucleic acids in circulation: Are they harmful to the host? J. Biosci. 2012, 37, 301-312.

14. Chen, X.; Ba, Y.; Ma, L.; Cai, X.; Yin, Y.; Wang, K.; Guo, J.; Zhang, Y.; Chen, J.; Guo, X.; et al. Characterization of microRNAs in serum: A novel class of biomarkers for diagnosis of cancer and other diseases. Cell Res. 2008, 18, 997-1006.

15. Chim, S.S.C.; Shing, T.K.F.; Hung, E.C.W.; Leung, T.Y.; Lau, T.K.; Chiu, R.W.K.; Lo, Y.M.D. Detection and characterization of placental microRNAs in maternal plasma. Clin. Chem. 2008, 54, 482-490.

16. Ma, R.; Jiang, T.; Kang, X. Circulating microRNAs in cancer: Origin, function and application. J. Exp. Clin. Cancer Res. 2012, 31, 38.

17. Zhang, C.; Wang, C.; Chen, X.; Yang, C.; Li, K.; Wang, J.; Dai, J.; Hu, Z.; Zhou, X.; Chen, L.; et al. Expression profile of microRNAs in serum: A fingerprint for esophageal squamous cell carcinoma. Clin. Chem. 2010, 56, 1871-1879.

18. Zhang, T.; Wang, Q.; Zhao, D.; Cui, Y.; Cao, B.; Guo, L.; Lu, S.H. The oncogenetic role of microRNA-31 as a potential biomarker in oesophageal squamous cell carcinoma. Clin. Sci. 2011, $121,437-447$.

19. Komatsu, S.; Ichikawa, D.; Takeshita, H.; Tsujiura, M.; Morimura, R.; Nagata, H.; Kosuga, T.; Iitaka, D.; Konishi, H.; Shiozaki, A.; et al. Circulating microRNAs in plasma of patients with oesophageal squamous cell carcinoma. Br. J. Cancer 2011, 105, 104-111.

20. Tsujiura, M.; Ichikawa, D.; Komatsu, S.; Shiozaki, A.; Takeshita, H.; Kosuga, T.; Konishi, H.; Morimura, R.; Deguchi, K.; Fujiwara, H.; et al. Circulating microRNAs in plasma of patients with gastric cancers. Br. J. Cancer 2010, 102, 1174-1179.

21. Zhou, H.; Guo, J.M.; Lou, Y.R.; Zhang, X.J.; Zhong, F.D.; Jiang, Z.; Cheng, J.; Xiao, B.X. Detection of circulating tumor cells in peripheral blood from patients with gastric cancer using microRNA as a marker. J. Mol. Med. 2010, 88, 709-717.

22. Liu, R.; Zhang, C.; Hu, Z.; Li, G.; Wang, C.; Yang, C.; Huang, D.; Chen, X.; Zhang, H.; Zhuang, R.; et al. A five-microRNA signature identified from genome-wide serum microRNA expression profiling serves as a fingerprint for gastric cancer diagnosis. Eur. J. Cancer 2011, 47, 784-791. 
23. Liu, H.; Zhu, L.; Liu, B.; Yang, L.; Meng, X.; Zhang, W.; Ma, Y.; Xiao, H. Genome-wide microRNA profiles identify miR-378 as a serum biomarker for early detection of gastric cancer. Cancer Lett. 2012, 316, 196-203.

24. Konishi, H.; Ichikawa, D.; Komatsu, S.; Shiozaki, A.; Tsujiura, M.; Takeshita, H.; Morimura, R.; Nagata, H.; Arita, T.; Kawaguchi, T.; et al. Detection of gastric cancer-associated microRNAs on microRNA microarray comparing pre- and post-operative plasma. Br. J. Cancer 2012, 106, 740-747.

25. Song, M.Y.; Pan, K.F.; Su, H.J.; Zhang, L.; Ma, J.L.; Li, J.Y.; Yuasa, Y.; Kang, D.; Kim, Y.S.; You, W.C. Identification of serum microRNAs as novel non-invasive biomarkers for early detection of gastric cancer. PLoS One 2012, 7, e33608.

26. Wang, M.; Gu, H.; Wang, S.; Qian, H.; Zhu, W.; Zhang, L.; Zhao, C.; Tao, Y.; Xu, W. Circulating miR-17-5p and miR-20a: Molecular markers for gastric cancer. Mol. Med. Report. 2012, 5, 1514-1520.

27. Wang, J.; Chen, J.; Chang, P.; LeBlanc, A.; Li, D.; Abbruzzesse, J.L.; Frazier, M.L.; Killary, A.M.; Sen, S. MicroRNAs in plasma of pancreatic ductal adenocarcinoma patients as novel blood-based biomarkers of disease. Cancer Prev. Res. 2009, 2, 807-813.

28. Kong, X.; Du, Y.; Wang, G.; Gao, J.; Gong, Y.; Li, L.; Zhang, Z.; Zhu, J.; Jing, Q.; Qin, Y.; et al. Detection of differentially expressed microRNAs in serum of pancreatic ductal adenocarcinoma patients: MiR-196a could be a potential marker for poor prognosis. Dig. Dis. Sci. 2011, 56, 602-609.

29. Liu, J.; Gao, J.; Du, Y.; Li, Z.; Ren, Y.; Gu, J.; Wang, X.; Gong, Y.; Wang, W.; Kong, X. Combination of plasma microRNAs with serum CA19-9 for early detection of pancreatic cancer. Int. J. Cancer 2011, 131, 683-691.

30. Morimura, R.; Komatsu, S.; Ichikawa, D.; Takeshita, H.; Tsujiura, M.; Nagata, H.; Konishi, H.; Shiozaki, A.; Ikoma, H.; Okamoto, K.; et al. Novel diagnostic value of circulating miR-18a in plasma of patients with pancreatic cancer. Br. J. Cancer 2011, 105, 1733-1740.

31. Liu, R.; Chen, X.; Du, Y.; Yao, W.; Shen, L.; Wang, C.; Hu, Z.; Zhuang, R.; Ning, G.; Zhang, C.; et al. Serum MicroRNA Expression profile as a biomarker in the diagnosis and prognosis of pancreatic cancer. Clin. Chem. 2012, 58, 610-618.

32. Yamamoto, Y.; Kosaka, N.; Tanaka, M.; Koizumi, F.; Kanai, Y.; Mizutani, T.; Murakami, Y.; Kuroda, M.; Miyajima, A.; Kato, T.; et al. MicroRNA-500 as a potential diagnostic marker for hepatocellular carcinoma. Biomarkers 2009, 14, 529-538.

33. Gui, J.; Tian, Y.; Wen, X.; Zhang, W.; Zhang, P.; Gao, J.; Run, W.; Tian, L.; Jia, X.; Gao, Y. Serum microRNA characterization identifies miR-885-5p as a potential marker for detecting liver pathologies. Clin. Sci. 2011, 120, 183-193.

34. Li, L.M.; Hu, Z.B.; Zhou, Z.X.; Chen, X.; Liu, F.Y.; Zhang, J.F.; Shen, H.B.; Zhang, C.Y.; Zen, K. Serum microRNA profiles serve as novel biomarkers for HBV infection and diagnosis of HBV-positive hepatocarcinoma. Cancer Res. 2010, 70, 9798-9807.

35. Xu, J.; Wu, C.; Che, X.; Wang, L.; Yu, D.; Zhang, T.; Huang, L.; Li, H.; Tan, W.; Wang, C.; et al. Circulating microRNAs, miR-21, miR-122, and miR-223, in patients with hepatocellular carcinoma or chronic hepatitis. Mol. Carcinog. 2011, 50, 136-142. 
36. Qu, K.Z.; Zhang, K.; Li, H.; Afdhal, N.H.; Albitar, M. Circulating microRNAs as biomarkers for hepatocellular carcinoma. J. Clin. Gastroenterol. 2011, 45, 355-360.

37. Zhou, J.; Yu, L.; Gao, X.; Hu, J.; Wang, J.; Dai, Z.; Wang, J.F.; Zhang, Z.; Lu, S.; Huang, X.; et al. Plasma microRNA panel to diagnose hepatitis B virus-related hepatocellular carcinoma. J. Clin. Oncol. 2011, 29, 4781-4788.

38. Qi, P.; Cheng, S.Q.; Wang, H.; Li, N.; Chen, Y.F.; Gao, C.F. Serum microRNAs as biomarkers for hepatocellular carcinoma in Chinese patients with chronic hepatitis B virus infection. PLoS One 2011, 6, e28486.

39. Li, J.; Wang, Y.; Yu, W.; Chen, J.; Luo, J. Expression of serum miR-221 in human hepatocellular carcinoma and its prognostic significance. Biochem. Biophys. Res. Commun. 2011, 406, 70-73.

40. Ng, E.K.; Chong, W.W.; Jin, H.; Lam, E.K.; Shin, V.Y.; Yu, J.; Poon, T.C.; Ng, S.S.; Sung, J.J. Differential expression of microRNAs in plasma of patients with colorectal cancer: A potential marker for colorectal cancer screening. Gut 2009, 58, 1375-1381.

41. Huang, Z.; Huang, D.; Ni, S.; Peng, Z.; Sheng, W.; Du, X. Plasma microRNAs are promising novel biomarkers for early detection of colorectal cancer. Int. J. Cancer 2010, 127, 118-126.

42. Wang, L.G.; Gu, J. Serum microRNA-29a is a promising novel marker for early detection of colorectal liver metastasis. Cancer Epidem. 2012, 36, e61-e67.

43. Cheng, H.; Zhang, L.; Cogdell, D.E.; Zheng, H.; Schetter, A.J.; Nykter, M.; Harris, C.C.; Chen, K.; Hamilton, S.R.; Zhang, W. Circulating plasma miR-141 is a novel biomarker for metastatic colon cancer and predicts poor prognosis. PLoS One 2011, 6, e17745.

44. Pu, X.X.; Huang, G.L.; Guo, H.Q.; Guo, C.H.; Li, H.; Ye, S.; Ling, S.; Jiang, L.; Tian, Y.; Lin, T.Y. Circulating miR-221 directly amplified from plasma is a potential diagnostic and prognostic marker of colorectal cancer and is correlated with p53 expression. J. Gastroenterol. Hepatol. 2010, 25, 1674-1680.

45. Weber, J.A.; Baxter, D.H.; Zhang, S.; Huang, D.Y.; Huang, K.H.; Lee, M.J.; Galas, D.J.; Wang, K. The microRNA spectrum in 12 body fluids. Clin. Chem. 2010, 56, 1733-1741.

46. Link, A.; Balaguer, F.; Shen, Y.; Nagasaka, T.; Lozano, J.J.; Boland, C.R.; Goel, A. Fecal MicroRNAs as novel biomarkers for colon cancer screening. Cancer Epidem. Biomark. Prev. 2010, 19, 1766-1774.

47. Hanke, M.; Hoefig, K.; Merz, H.; Feller, A.C.; Kausch, I.; Jocham, D.; Warnecke, J.M.; Sczakiel, G. A robust methodology to study urine microRNA as tumor marker: MicroRNA-126 and microRNA-182 are related to urinary bladder cancer. Urol. Oncol. 2010, 28, 655-661.

48. Hanson, E.K.; Lubenow, H.; Ballantyne, J. Identification of forensically relevant body fluids using a panel of differentially expressed microRNAs. Anal. Biochem. 2009, 387, 303-314.

(C) 2012 by the authors; licensee MDPI, Basel, Switzerland. This article is an open access article distributed under the terms and conditions of the Creative Commons Attribution license (http://creativecommons.org/licenses/by/3.0/). 